\title{
Agriculture in Motion: Intertwined Geographical and Socio-professional Mobilities in North Africa's Groundwater Economy
}

\author{
Marcel Kuper* \\ Mohamed Naouri** \\ Tarik Hartani***
}

\begin{abstract}
In this paper, we examine the greenhouse horticulture in Algeria's Sahara, which is one illustrative example of the agricultural transitions that have taken place in North Africa on the new irrigation frontiers created through groundwater use. The entrepreneurial farming systems in the region are characterized by considerable mobility. Geographic mobilities of people, ideas, capital, information, and objects and socio-professional mobilities are intrinsically intertwined, whereby skilled sharecroppers and laborers move sometimes over hundreds of kilometers, attracted by the opportunities of quick monetary gains and by the opportunities of rapid socio-professional upward mobility. This paper analyzes, first the different forms of socio-professional and geographical mobilities associated with the groundwater-based farming systems in Algeria's Sahara, with a particular focus on mobile young farmers; then focuses on the multiple borders that these young farmers crossed on their trajectory; and their return journey after they quit the Sahara.
\end{abstract}

Keywords: Agriculture, irrigation, groundwater, mobility, North Africa

\section{Özet}

Devinen Tarım: Kuzey Afrika'nın Yeraltı Suyu Ekonomisinde İç İçe Geçmiş Coğrafi ve Sosyo-profesyonel Hareketlilikler

Bu makalede, Kuzey Afrika'nın yeraltı suyu kullanımıyla oluşturulan sulama sınırlarındaki tarımsal dönüşümlerin aydınlatıcı örneklerinden biri olan Cezayir Sahra'sındaki sera bahçeciliği incelenmektedir. Bölgedeki girişimci tarım sistemleri, dikkate değer bir hareketlilik ile nitelenmektedir. İnsanların, fikirlerin, sermayenin, bilginin ve nesnelerin coğrafi hareketliliği ve sosyo-profesyonel hareketlilikler, ortakçı çiftçiler ve işçilerin, hızlı parasal kazançların ve sosyo-profesyonel yükselme olanaklarının çekiciliğine kapılarak bazen yüzlerce kilometre yer değiştirmeleri vasıtasıyla, özünde iç içe geçmiş durumdadırlar. Bu makale, hareketli genç çiftçileri odağına alarak, Cezayir Sahra'sındaki yeraltı suyu merkezli tarımsal sistemlerle ilişkili sosyo-profesyonel ve coğrafi hareketliliklerin farklı formlarını, bu genç çiftçilerin güzergahlarında geçtikleri çoklu sınırları ve Sahra'yı bırakmaları ardından yaptıkları geri dönüş yolculuklarını analiz etmektedir.

Anahtar sözcükler: Tarım, sulama, yeraltı suyu, hareketlilik, Kuzey Afrika

* CIRAD International Agricultural Research Centre For Development, France; Hassan II Institute of Agronomy and Veterinary Sciences (IAV), Morocco

** ENSA Higher National Agronomic School, Algeria; Hassan II Institute of Agronomy and Veterinary Sciences (IAV), Morocco

*** University Center Morsli Abdallah Tipaza, Algeria; ENSA Higher National Agronomic School, Algeria 


\section{Introduction}

In 1995, a farmer that we had met in the rich Mitidja plain in Northern Algeria had decided to invest in Saharan agriculture in Biskra, some $500 \mathrm{~km}$ to the south-east. Following urbanization in the fertile coastal plains in the north, in a context of limited land and water resources, he considered that "the future [was] in the South". ${ }^{1}$ Attracted by the possibility to produce early vegetables under greenhouses in a desert climate, encouraged by the agricultural subsidies and the availability of pumped groundwater, this farmer was one of the many who would contribute to a "renewal" of Saharan agriculture. ${ }^{2}$ Two decades later, this groundwater-based agricultural boom has transformed the landscape, as hyper-arid Saharan regions such as Biskra, El Ouedand Ouargla have become, paradoxically, some of the most productive agricultural departments (in terms of added value) of the country. For example, Biskra has become the main producer of vegetables under greenhouses, tomatoes in particular $(50 \%$ of the national production $^{3}$ ) and El Oued has become the first producer of potatoes irrigated by artisanal centre pivots ( $35 \%$ of the national production $\left.{ }^{4}\right)$. This is a typical example of what Shah has called a "groundwater economy", ${ }^{5}$ that is the rapid and massive development of agriculture in semi-arid and arid regions based on the intensive use of groundwater through mainly individual tube-wells. This particular groundwater economy opened up new irrigation frontiers on previously non-irrigated land, outside existing oases, enabling a rapid agricultural transition based on entrepreneurial agriculture. From a wider perspective, the groundwater economy in North Africa has expanded at a remarkable rate, especially since the 1980s. It is estimated that more than 500,000 farm holdings in Algeria, Morocco, and Tunisia, irrigating more than 1.75 million hectares (ha) land, are currently actively taking part in this groundwater economy. ${ }^{6}$

The opportunities offered on the new irrigation frontiers in Algeria's Sahara attracted many people (investors, young farmers, and laborers) often coming from several hundreds of kilometers away. In the Biskra district, for instance, $18,000-26,000$ young farmers are currently active in greenhouse horticulture. ${ }^{7}$

1 Amar Imache, Tarik Hartani, Sami Bouarfa and Marcel Kuper, La Mitidja vingt ans après: Réalités agricoles aux portes d'Alger (Algiers: Alpha Editions; Versailles: Editions Quae, 2011).

2 Marc Côte, "Des oasis aux zones de mise en valeur: L'étonnant renouveau de l'agriculture saharienne," Méditerranée 99, no. 3.4 (2002): 5-14.

3 Sami Assassi, Ali Daoudi and Caroline Lejars, "Les profits 'excessifs' des commerçants de fruits et légumes en Algérie: réalité ou préjugé infondé? Le cas de la tomate primeur à Biskra," Cahiers Agricultures 26, no. 2 (2017): 25002.

4 Abdelkrim Ould Rebai, Tarik Hartani, Mohammed Nacer Chabaca, and Marcel Kuper, "Une innovation incrémentielle: la conception et la diffusion d'un pivot d'irrigation artisanal dans le Souf (Sahara algérien)," Cahiers Agricultures 26, no. 3 (2017): 35005.

5 Tushaar Shah, Taming the Anarchy: Groundwater Governance in South Asia (Washington, DC: Resources for the Future; Colombo, Sri Lanka: International Water Management Institute, 2009).

6 Marcel Kuper, Nicolas Faysse, Ali Hammani, Tarik Hartani, Serge Marlet, Meriem Farah Hammamouche, and Fatah Ameur, "Liberation or Anarchy? The Janus Nature of Groundwater Use on North Africa's New Irrigation Frontiers," in Integrated Groundwater Management, ed. Anthony J. Jakeman, Olivier Barreteau, Randall J. Hunt, Jean-Daniel Rinaudo and Andrew Ross (Cham: Springer International Publishing, 2016), 583-615.

7 Mohamed Naouri, Tarik Hartani and Marcel Kuper, “The 'Innovation Factory': User-led Incremental Innovation of Drip Irrigation Systems in the Algerian Sahara," in Drip Irrigation for Agriculture: Untold Stories of Efficiency, Innovation and Development, ed. Jean-Philippe Venot, Marcel Kuper and Margreet Zwarteveen (London, New York: Routledge, Earthscan Studies in Water Resource Management, 2017), 266-283. 
They engage in intensive, entrepreneurial farming, strongly connected to the agricultural markets both for the inputs (e.g. seeds, fertilizers, and pesticides), technology (e.g. greenhouses, irrigation equipment) and for the marketing of agricultural production. Greenhouse horticulture in this area is an interesting mix of global farming systems, relying on external knowledge and marketing chains; but also dependent on local innovation systems, adapting equipment and practices to local (harsh) conditions. ${ }^{8}$ We have explained elsewhere that these young farmers are not only attracted to these irrigation frontiers to make money in what can be considered as highly profitable farming but also to gain the experience and capital to achieve upward social mobility. ${ }^{9}$ We focus on the mobility of the young farmers involved in greenhouse horticulture in the district of Biskra. In doing so, we hope to contribute to the emerging literature on the engagement of young family farmers in entrepreneurial agriculture, which may be temporary or permanent. ${ }^{10}$ The objective of this paper is, therefore, to analyze the different forms of social and geographical mobilities of young farmers who engage in the Sahara's entrepreneurial farming.

\section{Study Area and Research Approach}

The study took place in the Ziban (literally, an ensemble of oases), which is located in the administrative district (wilaya) of Biskra in the southeast of Algeria, approximately $500 \mathrm{~km}$ of the capital Algiers. Biskra, often considered as the gateway to the Sahara Desert, has been characterized by a very rapid agricultural development over the past 30 years, due to the availability of land promoted by the 1983 land reform, the access to pumped groundwater through deep tube-wells, the agricultural subsidies and the presence of peasantries keen to develop agriculture outside of the existing oases. ${ }^{11}$ The irrigated area of the Biskra district was multiplied by five, from 16,615 ha in 1969 to 83,350 ha in $2008 .^{12}$ In parallel, the number of date palms increased from 2 million in 1990 to 4.28 million in 2015, out of which $91 \%$ are producing dates..$^{13}$ The principal variety is degletnour, which is much appreciated on the domestic and international markets. Date palms were traditionally grown in layered oases with respectively

8 Naouri, Hartani and Kuper, “The 'Innovation Factory'," 266-283.

9 Farida Amichi, Sami Bouarfa, Caroline Lejars, Marcel Kuper, Tarik Hartani, Ali Daoudi, Hichem Amichi and Mohamed Belhamra, "Des serres et des hommes: des exploitations motrices de l'expansion territoriale et de l'ascension socioprofessionnelle sur un front pionnier de l'agriculture saharienne en Algérie," Cahiers Agricultures 24, no. 1 (2015): 11-19; Mohamed Naouri, Tarik Hartani and Marcel Kuper, "Mobilités des jeunes ruraux pour intégrer les nouvelles agricultures sahariennes (Biskra, Algérie)," Cahiers Agricultures 24, no. 6 (2015): 379-386; Mohamed Lamine Ouendeno, Ali Daoudi, and Jean-Philippe Colin, "Les trajectoires professionnelles des jeunes dans la néo-agriculture saharienne (Biskra, Algérie) revisitées par la théorie de l'agricultural ladder," Cahiers Agricultures 24, no. 6 (2015): 396-403.

10 Christine Okali and James Sumberg, "Quick Money and Power: Tomatoes and Livelihood Building in Rural Brong Ahafo, Ghana," IDS Bulletin 43, no. 6 (2012): 44-57; Hichem Amichi, Zakaria Kadiri, Sami Bouarfa and Marcel Kuper, “Une génération en quête d'opportunités et de reconnaissance: les jeunes ruraux et leurs trajectoires innovantes dans l'agriculture irriguée au Maghreb," Cahiers Agricultures 24, no. 6 (2015): 323-329; Olivier Petit, Marcel Kuper and Fatah Ameur, "From Worker to Peasant and Then to Entrepreneur? Land Reform and Agrarian Change in the Saïss (Morocco)," World Development 105 (2018): 119-131.

11 Côte, "Des oasis aux zones de mise en valeur," 5-14.

12 Kuper et al., "Liberation or Anarchy?," 583-615.

13 Salah Eddine Benziouche, “L'agriculture biologique, un outil de développement de la filière dattes dans la région des Ziban en Algérie," Cahiers Agricultures 26, no. 3 (2017): 35008. 
date palms, fruit trees and annual crops (e.g. cereals, fodder crops). Nowadays, date palms are often grown in mono-cropped, single variety palm groves outside the traditional oases. In addition, the Ziban are increasingly reputed for early season vegetables and fruits, such as tomatoes, bell peppers, eggplants, melons, watermelons that are produced in greenhouses. Greenhouse horticulture increased rapidly from 1,370 ha in 2000 to 5,165 ha in 2014, amounting to almost 130,000 greenhouses (a greenhouse typically measures $8 \mathrm{~m}$ by $50 \mathrm{~m}$ ). The Sahara, and in particular the Ziban, is indeed the only region in Algeria which provides vegetables to 40 million domestic consumers during the winter.

While in the past, the irrigated areas were concentrated in community-managed collective irrigation schemes in the traditional oases around artesian wel1s, springs, or diverted river flow through spate irrigation, more than $70 \%$ of the total irrigated area is now qualified as private or individual irrigation areas, relying exclusively on pumped groundwater..$^{14}$ Indeed, most of the rapid expansion of irrigated agriculture took place outside the traditional oases, thanks to access to the groundwater through a multitude of deep tube-wells. However, these new extensions did not develop independently from the existing oases. In many cases, young descendants of the oasis community left the traditional palm groves, where social constraints were considerable and economic opportunities limited, to engage in new forms of Saharan agriculture. Also, most of the investors engaging in "modern" palm groves originated from the Ziban. Some were local investors; others had made money elsewhere but came back to invest. However, the "renewal" of Saharan agriculture ${ }^{15}$ also attracted many outsiders to the area.

In this study, we will take a close look at the mobility linked to the greenhouse horticulture, which we consider as a frontier type of phenomenon in the Ziban. ${ }^{16}$ The setting of this case study differs from most studies of (inter)national labor migration in agriculture, where seasonal laborers move to established (large-scale) farms, for example in Australia ${ }^{17}$ or in Spain. ${ }^{18}$ In the case of Biskra, young men travel to engage, often as laborers, in small-scale greenhouse horticulture with the explicit ambition to rapidly climb the agricultural ladder to become sharecroppers and even farmers (e.g. lessees, landowners) in turn engaging other laborers and sharecroppers. In sum, we will show that geographical and socio-professional mobilities in our case are intrinsically linked.

Following the recent literature on this concept, we understand mobilities to include first both large-scale movements across the world and more local travel$\mathrm{s},{ }^{19}$ secondly, address not only people, but also "ideas, images, objects, waste products and money"; ;20 and finally, be as much a geographical as a social phenomenon,

14 Kuper et al., "Liberation or Anarchy?," 583-615.

15 Côte, “Des oasis aux zones de mise en valeur," 5-14.

16 Marcel Kuper, "Liberation or Anarchy?, 583-615; Farida Amichi, Sami Bouarfa, Marcel Kuper and Patrick Caron, "From Oasis Archipelago to Pioneering Eldorado in Algeria's Sahara," Irrigation and Drainage, forthcoming.

17 Nic Maclellan and Peter Mares, "Labour Mobility in the Pacific: Creating Seasonal Work Programs in Australia," Globalisation and Governance in the Pacific Islands (2006): 137-171.

18 Catalina Amuedo-Dorantes, "Work Transitions into and out of Involuntary Temporary Employment in a Segmented Market: Evidence from Spain," ILR Review 53, no. 2 (2000): 309-325.

19 Kevin Hannam, Mimi Sheller and John Urry, "Mobilities, Immobilities and Moorings," Mobilities 1, no. 1 (2006): 1-22.

20 John Urry, Sociology Beyond Societies: Mobilities for the Twenty-first Century (London, New York: Routledge, 2012). 
when it relates, for instance, to social upward (or downward) mobility. ${ }^{21}$ In addition, this literature emphasizes the fact that "people" and "places" should not be considered as distinct, as "there is a complex relationality of places and persons connected through performances". ${ }^{22}$ The network of connections stretching between places and people is of particular interest to this study.

We interviewed 42 different farmers, out of which 22 are considered as young (20-35 years old), based on the distinction made in the administrative subsidy schemes and 20 farmers are over 35 years old, but employ young men on their farms. Out of these 42 farmers, 24 came from the Ziban, while 18 farmers had come from other regions in Algeria. The sample is made up exclusively of male farmers, as the mobility related to greenhouse horticulture in this frontier area is restricted to men in practice. The 22 young farmers were mostly single at the time of the interviews, which facilitated their mobility. The sampling was based on (1) the farmer status (e.g. laborer, sharecropper, lessee, landowner), (2) the origin (native or coming from another area), and (3) the location of the farm on which he was active. The interviews focused on identifying: (1) the farming systems, including the farmers' relation with the land (e.g. owner, lessee or sharecropper), the cropping pattern (e.g. mono-cropped, multiple crops), the number of greenhouses, the source of capital (e.g. personal, credit, subsidies); and (2) the trajectory of each farmer (e.g. origin, experience in farming, involvement in agriculture in the Ziban).

\section{Greenhouse Horticulture at the Intersection of Social and Geographical Mo- bilities in the Ziban}

At the Heart of the Different Mobilities: Profitable and Mobile Farming Systems on Agricultural Frontiers

At the basis of the mobilities towards and inside the Ziban, are the very profitable and complementary farming systems of greenhouse horticulture and date palms. Installing a palm grove requires a considerable initial investment, including installing a tube-well and irrigation equipment, obtaining a land title, clearing the land, and buying the seedlings. Moreover, a date palm takes more than five years to start producing. The total investment and operational cost before the palm grove starts producing is in the range of 2,2 million Algerian Dinars (DA) per ha (about 16,300€ in 2017 rates). In order to finance this operation, many landowners rent out plots to lessees who install greenhouses, once these landowners have acquired and cleared the land and installed a tube-well and irrigation equipment. Greenhouse horticulture is very profitable in its own right (typically, 70,000€ per ha per season ${ }^{23}$ ) and also the advantage is that these profits are generated right from the first year. After a period of three years, the lessees generally move on to "new lands", as the soil gets exhausted through intensive horticulture, and the landowners take care of the palm trees that they have started to plant. Thus, the junction of both farming systems in the Ziban has created new agricultural frontiers, as farmers are constantly seeking new lands to perpetuate this mobile agricultural model. ${ }^{24}$

21 Mimi Sheller and John Urry, "The New Mobilities Paradigm," Environment and Planning A 38, no. 2 (2006): 207-226; Urry, Sociology Beyond Societies.

22 Sheller and Urry, "The New Mobilities Paradigm," 207-226.

23 Naouri, Hartani and Kuper, "Mobilités des jeunes ruraux," 379-386.

24 Amichi et al., "Des serres et des hommes," 11-19. 


\section{A Rapid Socio-professional Upward Mobility in Greenhouse Horticulture}

Young farmers sometimes compare working in greenhouses, which combine extremely high temperatures and unhealthy agricultural practices (application of pesticides, in particular), to the compulsory military service, which brings a lot of suffering, but only temporary for them..$^{25}$ These young men are very motivated to climb what can be called the "agricultural ladder" in this farming system ${ }^{26}$ to escape from the daily toil of those situated on the lower stairs of the ladder. Generally, they start as laborers and try to become sharecroppers as soon as possible. Each sharecropper handles five to ten greenhouses and can make up to $4,000 €$ per season, which is the equivalent salary of an engineer in Algerian the public sector. ${ }^{27}$ These sharecroppers are employed by the landowners, but more frequently by the lessees who rent in the land from the landowner. The lessees provide all the inputs to the sharecroppers with whom they contract, own the greenhouses and handle the marketing of the produce. These lessees, who have generally been sharecroppers before, are integrated into the highly structured, albeit informal, value chains through which they benefit from the credit system put in place by inputs sellers. ${ }^{28}$ A lessee can obtain up to $1000 €$ net benefits per greenhouse per season (typically a rotation of tomato/melon). In the Ziban, lessees often have several tens of greenhouses, leading to considerable annual gains. Most of the lessees remain in this business for several years, gradually increasing the number of greenhouses, before investing in other activities. Some of the lessees become landowners and plant palm trees, which constitute perhaps the final step of the ladder, while others remain lessees and invest in other economic activities. Out of the 22 young farmers we interviewed, eight started as laborers, while the others started directly as sharecroppers. Out of these eight ex-laborers, seven are now lessees and one has even become a landowner and date producer.

\section{A Geographical Mobility Based on Expertise and the Capacity to Innovate}

On a typical plot of 10 ha of greenhouse horticulture, 30-75 farmers will be active, which explains the high demand for young sharecroppers and laborers in the Ziban, in particular, those who already have an experience in greenhouse horticulture. ${ }^{29}$ In 2014, the total area under greenhouse horticulture was estimated to be 5,165 ha on which about 18,000 to 26,000 young farmers were active. Young farmers come from hundreds of kilometers away to work in greenhouse horticulture, attracted by the profitable farming systems and quick gains. In addition, some local young men also engage in the greenhouse horticulture once they observe the significant gains that can be obtained. Young men are recruited through informal networks of family/kinship/friendship/fellow villagers and never by formal ways of recruitment. The recruitment of these young farmers obeys to very precise criteria. Every home region is reputed for a specific farming system. For example, Tipaza (to the west of the Mitidja plain and

25 Naouri, Hartani and Kuper, "Mobilités des jeunes ruraux," 379-386.

26 Ali Daoudi Ouendeno and Jean-Philippe Colin, "Les trajectoires professionnelles des jeunes dans la néo-agriculture saharienne," 396-403.

27 Naouri, Hartani and Kuper, "Mobilités des jeunes ruraux," 379-386.

28 Caroline Lejars, Ali Daoudi and Hichem Amichi, “The Key Role of Supply Chain Actors in Groundwater Irrigation Development in North Africa," Hydrogeology Journal 25, no. 6 (2017): 1593-1606.

29 Naouri, Hartani and Kuper, “Mobilités des jeunes ruraux," 379-386. 
more than $600 \mathrm{~km}$ away from the Ziban) is renowned for tomato production under greenhouses and the knowledge of its producers (e.g. selection of seeds, dealing with diseases, application of irrigation and fertilizers). Young men from Tipaza are, therefore, actively recruited for tomato production by the lessees, some of whom are also from this area. Other young men come from Médéa or Ain Defla, which are the areas reputed for the production of bell peppers. Young men from nearby districts (e.g. Batna, Khenchela) are not only recruited for greenhouse horticulture, but also for vegetable plots without greenhouses. More generally, sharecroppers are not only recruited for their expertise, but also for their resourcefulness and their capacity to adapt equipment and practices to local climatic and socio-economic conditions. What travel here are not only the innovations themselves, but also the capacity to innovate. ${ }^{30}$

The sharecroppers are attracted by the financial gains, as discussed above, but also by the possibility of rapid upward social mobility. We have shown elsewhere that in addition to these large-scale movements, there is also a lot of local mobility of these sharecroppers within the Ziban, who are always looking for opportunities of status and financial gains. ${ }^{31}$ For example, with only two years of experience in the west of the Ziban, sharecroppers can move to the east of the Ziban to become qualified sharecroppers in Canarian greenhouses. There, they gain sufficient money and experience to return to the west to become small-scale lessees. This situation confirms the statement of Sheller and Urry: "Moving between places physically or virtually can be a source of status and power". ${ }^{32}$

Apart from this big mass of mobile sharecroppers, there are also some other more specific geographical mobilities, often associated with the demands for highly specialized expertise and innovation. For instance, in 2009 the first Canarian greenhouse (1-6 ha) was imported from Morocco. This type of greenhouse is much larger than the classic greenhouses of the Ziban $(8 \times 50 \mathrm{~m})$ and also allows for vertical intensification through higher tomato plants (up to $3 \mathrm{~m}$ ). Rather than importing the physical object, which was difficult given the distance and the size of the object, the local farmers called on Moroccan technicians, who travelled to the Ziban, to design and install these greenhouses. Those technicians also trained local sharecroppers and laborers on the new agricultural practices required for this type of greenhouse. This shows how the mobility of specific objects and ideas lead to the mobility of people. More generally, the highly intensive greenhouse horticulture requires the presence of several hundreds of engineers, sales agents, and retailers. This corps of service providers is an interesting mix of people coming from other regions of Algeria, having specific expertise, and local people, who both expertise and have good local networks.

\section{The Pooling of Resources Leads to the Mobility of Capital, Labor, and Objects}

The way greenhouse horticulture in the Ziban is organized can be referred to as the pooling of productive resources by different actors involved in farming. ${ }^{33}$ In a typical farming configuration, the landowner brings in the land and the access to water, the lessee provides the capital necessary for installing the greenhouses and financing the agricultural season, the marketing expertise as well

30 Naouri, Hartani and Kuper, “The 'Innovation Factory'," 266-283.

31 Naouri, Hartani and Kuper, "Mobilités des jeunes ruraux," 379-386.

32 Sheller and Urry, "The New Mobilities Paradigm," 207-226.

33 Amichi et al., “Des serres et des hommes," 11-19. 
as the technical know-how for production, the sharecropper furnishes qualified labor and the capacity to innovate, and the laborer the workforce. We already showed above how this configuration led to a high demand for specialized labor, leading to an impressive set of geographical mobilities, but also to rapid upward social mobilities. This labor mobility is associated with a high mobility of capital, due to the high amount of transactions of inputs, linked to the very intensive farming systems. ${ }^{34}$ These inputs are partly imported (e.g. seeds or pesticides) or produced in other parts of the country (e.g. fertilizers) and travel over long distances. These objects are traded in dense networks of service providers, starting from the multinational companies up to the local retailers. These networks make available the different inputs to all of the active farmers in greenhouse horticulture and are strongly linked to the informal credit systems that enable the flux of inputs, and thus, the intensive farming systems.

Lejars et al. ${ }^{35}$ made a description of the informal credit systems that are dominant in the study area due to the insufficiency of formal credit schemes. Basically, this is a multi-tiered system in which the big (inter)national companies (e.g. manufacturers and/or importers) selling seeds, pesticides and fertilizers provide credit to their customers, the wholesalers, as part of a marketing strategy in competitive markets. These wholesalers then provide credit to their customers, the regional and local inputs sellers, who in turn provide credit to individual farmers, mainly lessees. Lejars et al ${ }^{36}$ explain how informal credit is reserved to "creditworthy and valued customers", which is determined through various criteria, while other farmers have to pay cash for their inputs. Credit is generally reimbursed 6-12 months later, once the farmers have sold their produce. The sales of agricultural produce are mostly undertaken on the wholesale markets in the region. Traders from all over the country, travel hundreds of kilometers, meet the farmers on these markets and then move the produce generally to the main urban centers of Algeria. The credit is generally provided through the physical objects, i.e. the farming inputs, which are often imported from abroad and enter the country through different ports (e.g. irrigation equipment, fertilizers, pesticides), airports (e.g. seeds), and then travel further to Biskra. Only after these inputs are reimbursed, the money travels in the opposite direction.

\section{On the Connections Between "Places" and "People"}

The literature cautions us against considering the "people", engaged in this frontier type of agriculture and often coming through geographical mobilities from far away, and the "places" where these agricultural dynamics are occurring as distinct. ${ }^{37}$ While greenhouse horticulture (locally named as plasticulture, which refers to the plastic-covered tunnel greenhouses) in the Sahara may seem at first as an agricultural activity disconnected to a large extent from the local agricultural dynamics, it is firmly embedded in reality. In particular, greenhouse horticulture generally finances the extension of date palm groves. ${ }^{38}$ In the composite landscape of the extensions, where new palm plantations and greenhouse horticulture are juxtaposed, the contributions of external actors (e.g. lessees and sharecroppers), and thus of geographic mobilities, are very important

34 Lejars et al., "The Key Role of Supply Chain Actors,” 1593-1606.

35 Lejars et al., "The Key Role of Supply Chain Actors," 1593-1606.

36 Lejars et al., “The Key Role of Supply Chain Actors,” 1593-1606.

37 Urry, Sociology Beyond Societies.

38 Amichi et al., “Des serres et des hommes," 11-19. 
in terms of capital, know-how, and workforce, as we showed above. However, these actors have multiple interactions with local farmers (e.g. the landowners) when engaging in greenhouse horticulture. These landowners play an important role in stimulating the on-going agricultural dynamics. In addition, some of the external actors decided to convert to date palm growing, thereby engaging in a learning process from local date palm growers. Also, there are quite a number of local farmers who get involved in greenhouse horticulture, as shown by the high proportion of local farmers in our sample. Some of these are now considered as leaders in the greenhouse farming systems. In sum, and as Côte ${ }^{39}$ hypothesized, the Ziban has turned out to be a dynamic and "modern" centre for agricultural development precisely because of the presence of particularly active peasantries engaging in entrepreneurial agriculture on the new irrigation frontiers. However, this was only possible through the close interactions and mingling with thousands of mobile young men coming from far away, and bringing in capital, skill and their workforce, and thus, through the strong connections between mobile "people" and "places". Indeed, the idea of a creatio ex nihilo of "modern" Saharan agriculture, i.e. an agricultural development created by outside intervention ignoring existing dynamics and merely taking advantage of the available resources (principally land, water and temperature in winter and spring) has been refuted..$^{40}$ For example, Hamamouche et al ${ }^{41}$ show that the two Saharan agricultural landscapes, the ancient oases, and the new extensions, are firmly connected in the Ziban. In both landscapes, the same actors are active and their diverse farming systems now rely all on pumped groundwater.

\section{Discussion}

\section{Crossing Multiple Borders Through Geographic and Social Mobilities to Par- take in the Saharan Groundwater Economy}

In this paper, we analyzed the different intertwined forms of geographic and social mobilities in the Algerian Sahara through a case study in Biskra. These mobilities are related mainly to young men engaging in entrepreneurial greenhouse agriculture as lessees or sharecroppers. These young men often travelled hundreds of kilometers and accepted to live in precarious conditions to take part in a groundwater economy, which is sometimes labeled as an "Eldorado of sands". ${ }^{42}$ Their ambition was to make money, as greenhouse horticulture has been very profitable, but also to climb the agricultural ladder. ${ }^{43}$ Indeed, the groundwater economy in Biskra developed in frontier conditions with many possibilities for socio-economic advancement in a relatively short time.

Our case study shows that geographic and social mobilities are intrinsically linked. ${ }^{44}$ Young men cross multiple borders thanks to these mobilities. Firstly, they cross some physical and agro-ecological borders during their journey, as

39 Côte, "Des oasis aux zones de mise en valeur," 5-14.

40 Ali Bensaâd, ed., L'eau et ses enjeux au Sahara (Paris: Karthala, 2011); Meriem Farah Hamamouche, Marcel Kuper, Hichem Amichi, Caroline Lejars and Tarik Ghodbani, "New Reading of Saharan Agricultural Transformation: Continuities of Ancient Oases and Their Extensions (Algeria)," World Development 107 (2018): 210-223.

41 Hamamouche, et al., "New Reading of Saharan Agricultural Transformation," 210-223.

42 Jean Bisson, Mythes et réalités d'un désert convoité: le Sahara (Paris: Editions L'Harmattan, 2003): 233.

43 Ouendeno et al., "Les trajectoires professionnelles des jeunes dans la néo-agriculture saharienne," 396-403.

44 Naouri, Hartani and Kuper, “Mobilités des jeunes ruraux," 379-386. 
they generally hail from the more temperate northern coastal plains. They usually rely on their compatriots, who preceded them to the Sahara, to acclimatize to these new conditions; thus, taking advantage of existing socio-professional networks. This situation relates to adapting agricultural practices, but also more generally to adjusting to the living conditions in an unknown territory. Other people come from even further away and cross international borders like the Syrians reputed for drilling deep tube-wells or the Moroccans installing and managing Canarian greenhouses. In line with Urry ${ }^{45}$, we have also shown that it is not only people crossing such borders, but also ideas and objects, such as the internationally developed seeds and pesticides (as an object), the Canarian greenhouses (as an idea), the capital necessary to conduct intensive horticulture, the capacity to innovate (through geographic mobilities of skilled sharecroppers), or the tube-well equipment (as an object), which heavily relies on second-hand equipment from the oil industry in the Sahara. However, despite the fact that the geographic mobilities of men, ideas, information, and objects come together in the highly profitable farming systems of greenhouse horticulture, the functioning of these farming systems relied on the constant adaptation of practices, ideas and objects to local conditions. This explains the central place taken by these young mobile men in these farming systems.

Secondly, the prospect of quick profits and rapid social mobilities, associated with greenhouse horticulture, encouraged these young men to accept the extremely difficult conditions in which they had to work, in addition to the lack of social facilities at the first few years upon their arrival. It was, therefore, no surprise that these young men would reconnect to the city, as soon as this was materially possible. This situation was especially the case for those men who managed to become lessees, which required less of a physical presence in the greenhouse. Their dream was then to be on the farm in the morning and in a café at the centre of town in the afternoon, thus crossing frequently the borders of rural and urban spaces. ${ }^{46}$ Upward socio-professional mobility enabled more profitable economic activities but was also and perhaps foremost about quitting as soon as possible the difficult conditions of the field workers. In addition, their engagement in this frontier-type agriculture certainly accelerated their coming of age, as they would dispose of a small capital in their early twenties, opening up new socio-professional opportunities. Some would pursue in greenhouse agriculture, climbing the agricultural ladder. Others would engage with other professional activities, such as transport or marketing. Many would also make the choice to go back to their home districts.

\section{What Happens on the Return Journey?}

Urry ${ }^{47}$ questioned the "implications these mobilities have for the experiences of time, space, dwelling and citizenship". The question is then what happens on the return journey of those young men that engaged in greenhouse horticulture in the $\mathrm{Zi}$ ban. An interesting study on tomato production in Ghana ${ }^{48}$ showed how young people would seek "quick money" and autonomy through an engagement with entrepreneurial and highly intensive agriculture. These young people were

45 Urry, Sociology Beyond Societies.

46 Naouri, Hartani and Kuper, “Mobilités des jeunes ruraux," 379-386.

47 Urry, Sociology Beyond Societies.

48 Okali and Sumberg, "Quick Money and Power: Tomatoes and Livelihood," 44-57. 
shown to have a very instrumental relationship to this type of agriculture, which for many did not constitute a long-term engagement. This seems very similar in the case of greenhouse horticulture in the Ziban, as shown by the rapid turnover of laborers and sharecroppers. However, there are also differences. We met many young men who went back to their home districts to engage in greenhouse horticulture there. This concerned first those sharecroppers who did not manage upward social mobility and could not become lessees in the Ziban. In our study, such sharecroppers were the most vulnerable category of young farmers to return home. The main reason for going home for them was the additional suffering of working in the desert far away from home. Over the last few years, the daily salary went up in their home districts (10€ for 4 hours of work) and they have time while working in greenhouse horticulture, to do something else during the rest of the day. Many of those who went back to the north stayed in greenhouse and field horticulture, half of the day working for other farmers, and the other half in their own rented greenhouses or taking care of livestock. These farmers tend to diversify their farming systems, for instance by buying some livestock (mainly goats), or they go towards open field horticulture. The second reason is the desire to start a family life when these young men reach their late twenties. The majority of them went to the Ziban when they were single, but after marriage or having kids, they preferred to endure the hardships of greenhouse horticulture close to their family homes. The return journey also depends on what their goals were before going to the Ziban. Some of them wanted to build a house in their home district and to get married; others wanted to start a new life elsewhere and considered greenhouse horticulture as their main business. The return to the home districts does not mean automatically a failure, as many young men feel that they reached their goals. In addition, many had obtained some capital, making it easier to engage in farming or other economic activities in their home districts. Those farmers who climbed the agricultural ladder and managed to become lessees in the Ziban were more likely to stay there. They got more involved in the farming systems of the Ziban and this relationship is harder to break as they have made investments in greenhouses and in some cases in the land. The majority of the lessees is generally attached to greenhouse agriculture but remains very mobile. Even if the majority stays there where the land is more profitable such as in the south in places like the Ziban; some lessees went back and rented land in their home districts or in other districts in the north where the land access is easier than at home, but in a similar climate to their homeland.

\section{Conclusion}

We have shown how the recent agricultural groundwater-based boom in Algeria's Sahara was made possible due to a perhaps unique imbrication of both geographic and social mobilities of people, ideas, information, and objects, deeply connected in many ways to local agricultural dynamics and more global farming systems. Nowhere can be an island, in particular, "in the case of the complex trading and travel routes that constituted the Mediterranean world over many centuries" as Fernand Braudel posited in his reputed work on the Mediterranean at the time of Philip II. ${ }^{49}$ The oases, often portrayed as islands in a hostile desert, were firmly connected to the trans-Saharan exchanges in the past before their decline from the $16^{\text {th }}$ century onwards. Côte ${ }^{50}$ even refers to the advent of

49 Sheller and Urry, "The New Mobilities Paradigm," 207-226.

50 Côte, "Des oasis aux zones de mise en valeur," 5-14. 
agriculture in these oases as a "by-product" of this long-distance trade and of a world based on a "vie de relation" (a relational life). Algeria's Sahara today is once again connected in a myriad of ways to the new globalization as described by authors such as Firth ${ }^{51}$, which means that agricultural development in even these far-flung places can only be understood when accounting for the different interlinked geographic and social mobilities of people, ideas, information and objects that we revealed.

\section{Acknowledgements}

The research for this article was conducted in the framework of the "Groundwater Arena" project, financed by Agence Nationale de la Recherche (ANR). We thank the organizers of the Symposium "Mediterranean in Motion" and the Izmir Mediterranean Academy for having given us the opportunity to present and discuss this paper during the Symposium.

\section{Bibliography}

Amichi, Farida, Sami Bouarfa, Caroline Lejars, Marcel Kuper, Tarik Hartani, Ali Daoudi, Hichem Amichi, and Mohamed Belhamra. "Des serres et des hommes: des exploitations motrices de l'expansion territoriale et de l'ascension socio professionnelle sur un front pionnier de l'agriculture saharienne en Algérie." Cahiers Agricultures 24, no. 1 (2015): 11-19.

Amichi, Hichem, Zakaria Kadiri, Sami Bouarfa, and Marcel Kuper. "Une génération en quête d'opportunités et de reconnaissance: les jeunes ruraux et leurs trajectoires innovantes dans l'agriculture irriguée au Maghreb." Cahiers Agricultures 24, no. 6 (2015): 323-329.

Amichi, Farida, Sami Bouarfa, Marcel Kuper, and Patrick Caron. "From Oasis Archipelago to Pioneering Eldorado in Algeria's Sahara." Irrigation and Drainage, forthcoming.

Amuedo-Dorantes, Catalina. "Work Transitions into and out of Involuntary Temporary Employment in a Segmented Market: Evidence from Spain." ILR Review 53, no. 2 (2000): 309-325.

Assassi, Sami, Ali Daoudi, and Caroline Lejars. "Les profits 'excessifs' des commerçants de fruits et légumes en Algérie: réalité ou préjugé infondé? Le cas de la tomate primeur à Biskra." Cahiers Agricultures 26, no. 2 (2017), 25002.

Bensaâd, Ali, ed. L'eau et ses enjeux au Sahara. Paris: Karthala Editions, 2011.

Benziouche, Salah Eddine. "L'agriculture biologique, un outil de développement de la filière dattes dans la région des Ziban en Algérie." Cahiers Agricultures 26, no. 3 (2017): 35008.

Bisson, Jean. Mythes et réalités d'un désert convoité: le Sahara. Paris: Editions L'Harmattan, 2003.

Côte, Marc. "Des oasis aux zones de mise en valeur: L'étonnant renouveau de l'agriculture saharienne." Méditerranée 99, no. 3.4 (2002): 5-14.

Firth, Stewart. Globalization and Governance in the Pacific Islands: State, Society and Governance in Melanesia. ANU Press, 2013.

Hamamouche, Meriem Farah, Marcel Kuper, Hichem Amichi, Caroline Lejars, and Tarik Ghodbani. "New Reading of Saharan Agricultural Transformation: Continuities of Ancient Oases and Their Extensions (Algeria)." World Development 107 (2018): 210-223.

51 Stewart Firth, Globalization and Governance in the Pacific Islands: State, Society and Governance in Melanesia (ANU Press, 2013), 427. 
Hannam, Kevin, Mimi Sheller, and John Urry. "Mobilities, Immobilities and Moorings." Mobilities 1, no. 1 (2006): 1-22.

Imache, Amar, Tarik Hartani, Sami, Bouarfa, and Marcel Kuper. La Mitidja vingt ans après: Réalités agricoles aux portes d'Alger. Algiers: Alpha Editions; Versailles: Editions Quae, 2011.

Kuper, Marcel, Nicolas Faysse, Ali Hammani, Tarik Hartani, Serge Marlet, Meriem Farah Hamamouche, and Fatah Ameur. "Liberation or Anarchy? The Janus Nature of Groundwater Use on North Africa's New Irrigation Frontiers." In Integrated Groundwater Management, edited by Anthony J. Jakeman, Olivier Barreteau, Randall J. Hunt, Jean-Daniel Rinaudo and Andrew Ross, 583-615. Cham: Springer International Publishing, 2016.

Lejars, Caroline, Ali Daoudi, and Hichem Amichi. “The Key Role of Supply Chain Actors in Groundwater Irrigation Development in North Africa." Hydrogeology Journal 25, no. 6 (2017): 1593-1606.

Maclellan, Nic, and Peter Mares. "Labor Mobility in the Pacific: Creating Seasonal Work Programs in Australia." Globalization and Governance in the Pacific Islands. 2006: 137-171.

Naouri, Mohamed, Tarik Hartani, and Marcel Kuper. "Mobilités des jeunes ruraux pour intégrer les nouvelles agricultures sahariennes (Biskra, Algérie)." Cahiers Agricultures 24, no. 6 (2015): 379-386.

Naouri, Mohamed, Tarik Hartani, and Marcel Kuper. “The 'Innovation Factory': User-led Incremental Innovation of Drip Irrigation Systems in the Algerian Sahara." In Drip Irrigation for Agriculture: Untold Stories of Efficiency, Innovation and Development, edited by Jean-Philippe Venot, Marcel Kuper and Margreet Zwarteveen, 266-283. London and New York: Routledge, Earthscan Studies in Water Resource Management, 2017.

Okali, Christine, and James Sumberg. "Quick Money and Power: Tomatoes and Livelihood Building in Rural Brong Ahafo, Ghana." IDS Bulletin 43, no. 6 (2012): 44-57.

Ouendeno, Mohamed Lamine, Ali Daoudi, and Jean-Philippe Colin. "Les trajectoires professionnelles des jeunes dans la néo-agriculture saharienne (Biskra, Algérie) revisitées par la théorie de l'agricultural ladder." Cahiers Agricultures 24, no. 6 (2015): 396-403.

Petit, Olivier, Marcel Kuper, and Fatah Ameur. "From Worker to Peasant and Then to Entrepreneur? Land Reform and Agrarian Change in the Saïss (Morocco)." World Development 105 (2018): 119-131.

Rebai, Abdelkrim Ould, Tarik Hartani, Mohammed Nacer Chabaca, and Marcel Kuper. "Une innovation incrémentielle: la conception et la diffusion d'un pivot d'irrigation artisanal dans le Souf (Sahara algérien)." Cahiers Agricultures 26, no. 3 (2017): 35005.

Shah, Tushaar. Taming the Anarchy: Groundwater Governance in South Asia. Washington, DC: Resources for the Future; Colombo, Sri Lanka: International Water Management Institute, 2009.

Sheller, Mimi, and John Urry. "The New Mobilities Paradigm." Environment and Planning A 38, no. 2 (2006): 207-226.

Urry, John. Sociology Beyond Societies: Mobilities for the Twenty-first Century. London, New York: Routledge, 2012. 